\title{
35. THE FORMATION OF DOLOMITE IN SEDIMENTS FROM THE CONTINENTAL MARGIN OF NORTHEASTERN QUEENSLAND ${ }^{1}$
}

\author{
Peter K. Swart ${ }^{2}$
}

\begin{abstract}
The occurrence of dolomite in young Pleistocene sediments off the northeastern coast of Australia offers a special opportunity to examine dolomite formation relative to the original mineralogy and the remineralization of organic material through the processes of sulfate reduction and methanogenesis. The four cores examined in this study form a transect from shallow to deep water (Sites 821, 820, 819, and 822). At all sites, dolomite occurs in sediments of Pleistocene age and is more abundant closer to the continental margin (Site 821) than in sediments found in deeper water (Sites 819 and 822). In spite of the fact that the classic diagenetic zones of sulfate reduction and methanogenesis were all well developed at Sites $819,820,821$, and 822 , the $\delta^{13} \mathrm{C}$ of the interstitial dissolved inorganic carbon (DIC) showed no evidence of these diagenetic processes. The dolomites retrieved from sediments showed $\delta^{13} \mathrm{C}$ values similar to that of the DIC. The isotopic composition of the dolomite revealed no evidence of having been formed in either the sulfate reduction zone or the zone of methanogenesis. The Leg 133 sites differ from other anoxic hemipelagic areas in which extensive sulfate reduction and methanogenesis have been documented in that the sediments are dominated by $\mathrm{CaCO}_{3}$. Recrystallization of calcium carbonate apparently buffers the isotopic composition of the system, masking large isotopic changes that might be induced by additions of isotopically light or heavy $\mathrm{CO}_{2}$ derived from the processes of sulfate reduction and methanogenesis. The dolomite does not appear to be preferentially located in the portion of the cores in which sulfate is absent. Based on the association between the abundance of high-Mg calcite (HMC) and dolomite, it is thought that dolomites formed in response to the dissolution of HMC.
\end{abstract}

\section{INTRODUCTION}

The formation of dolomite in continental organic-rich sediments has been studied mainly in anoxic silicate-dominated sequences. Examples of such studies include the Gulf of California (Kelts and McKenzie, 1982), the Miocene-aged Monterey Formation (Burns et al., 1988; Burns and Baker, 1987; Compton and Siever, 1986; Baker and Burns, 1985; Pisciotto, 1981), the Miocene-aged Hawthorn Formation in the southeastern United States (Prasad, 1985), and the sediments cored during Leg 112 off the Peru margin (Kastner et al., 1990). In the majority of these studies, the formation of dolomite is considered to have occurred in situ under the influence of the oxidation of organic material by sulfate. As regards currently accepted models of dolomitization, such an occurrence fulfills at least two criteria. First, the removal of the sulfate ion, which may act as an inhibitor in the process of dolomitization (Baker and Kastner, 1981). Second, as a consequence of this process. $\mathrm{CO}_{2}$ is added to the pore waters, causing the dissolution of the precursor carbonate and increasing the alkalinity. This increases the saturation state of the pore fluids relative to dolomite, hence, promoting its formation (Land, 1985; Machel and Mountjoy, 1986).

The process of organic material oxidation by sulfate typically produces an extremely depleted carbon isotopic composition in the pore water-dissolved inorganic carbon (DIC), which in turn can be recorded by authigenic carbonates, including dolomites (Irwin et al., 1977; Friedman and Murata, 1979; Pisciotto, 1981; Pisciotto and Mahoney, 1981; Kelts and McKenzie, 1982). In fact, a characteristic signature of organic dolomites has been considered to be an isotopically depleted or enriched carbon isotopic ratio. Although many geological examples have been assigned to the sulfate-organic-rich model of dolomitization, few studies have been able to document the process in modern to Pleistocene-aged sediments and to combine such documentation with measurement of the relative geochemical con-

\footnotetext{
${ }^{1}$ McKenzie, J.A., Davies, P.J., Palmer-Julson, A., et al., 1993. Proc. ODP, Sci. Results, 133: College Station, TX (Ocean Drilling Program).

${ }^{2}$ Stable Isotope Laboratory, MGG/RSMAS, University of Miami, Miami, FL 33149, U.S.A.
}

stituents in the pore water. This study documents such associations between the pore-water chemistry and the occurrence of dolomite in mixed carbonate-siliclastic sediments that occur off the Queensland continental margin. As these zones are so well developed, one can test the ideas proposed that diagenetic carbonates (Claypool and Kaplan, 1974; Irwin et al., 1977) record the carbon isotopic signatures of the various diagenetic zones, in particular those imparted by sulfate reduction and methanogenesis.

In this study, I have measured the usual geochemical parameters on squeezed sediment samples on board the JOIDES Resolution, as well as performed carbon and oxygen isotopic analyses on the fluids and separated dolomite. Finally, I have synthesized data obtained from the organic geochemistry, biostratigraphy, and sedimentology to obtain an integrated model of dolomitization.

\section{SITES}

Sites $822,819,820$, and 821 form a distal-to-proximal transect off the northeastern margin of the Great Barrier Reef (Figs. 1 and 2). The water depths and penetration at each site are listed in Table 1. Despite having cored approximately $400 \mathrm{~m}$ at each site during Leg 133 , the oldest age of the sediment is only early Pleistocene, with the exception of Site 822, where the sedimentation rates are slightly depressed and latest-Pliocene-aged material was cored (Table 2). Sedimentation is nearly continuous at Sites 821 and 820 , while at Sites 822 and 819 , a hiatus of approximately 195 k.y. is seen between CN15 and CN14a (Davies, McKenzie, Palmer-Julson, et al., 1991). The sediments at each of the sites are similar, consisting of rhythmically bedded mixtures of siliciclastics (clay minerals, quartz, and feldspar) and periplatform carbonates (low-Mg calcite, aragonite, and high-Mg calcite). The variations in carbonate content at these sites appear to be related to fluctuations in influx from the adjacent Great Barrier Reef that have been induced through changes in sea level. Superimposed on these changes in absolute carbonate content are variations in the percentage of low-Mg calcite (LMC), high-Mg calcite (HMC), aragonite, and dolomite (Fig 3). Although the chronostratigraphy does not appear to be correlated with the mineralogy at Sites 821 and 820 , the only dolomite present at Sites 819 and 822 occurs just below the hiatus 


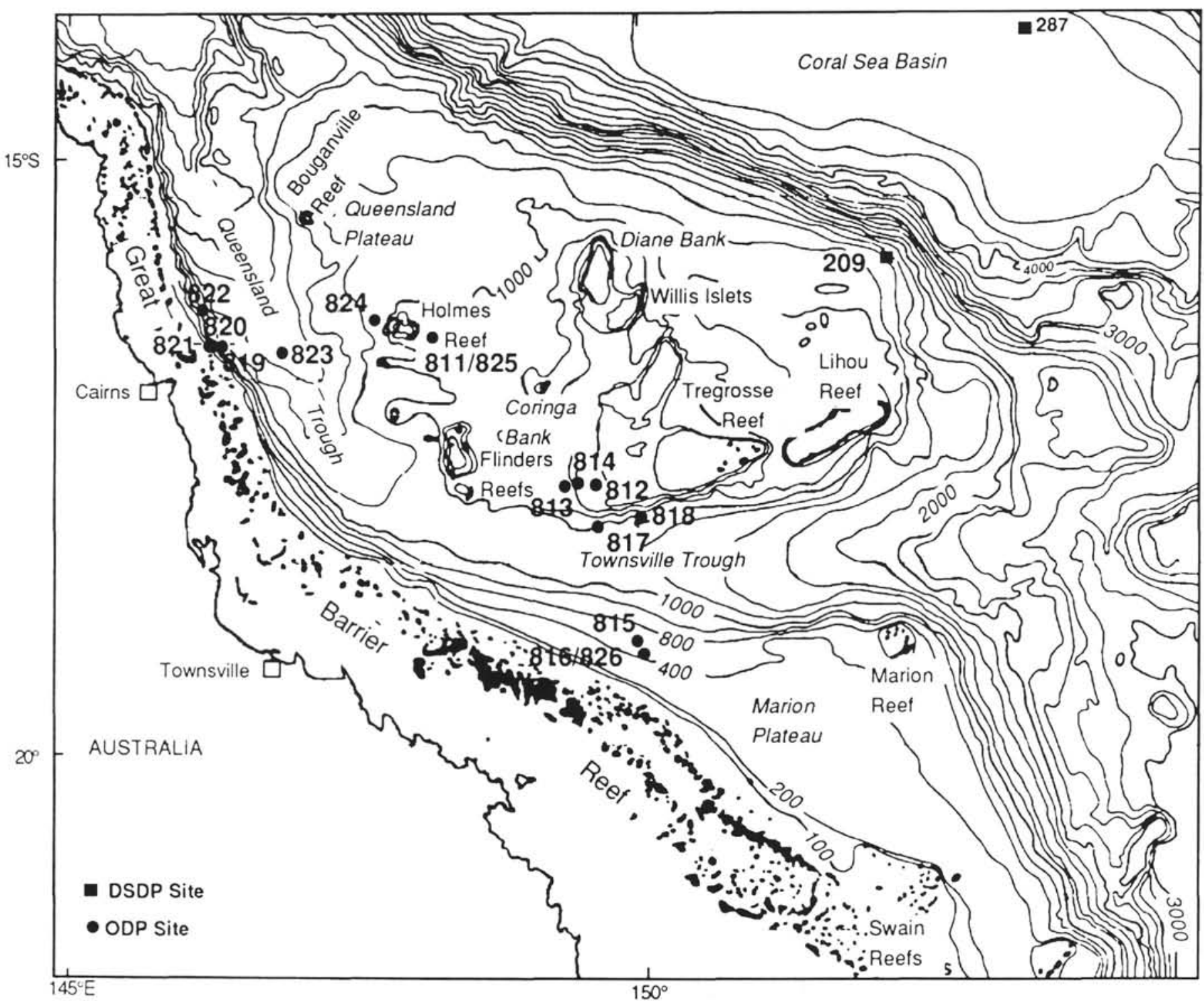

Figure 1. Location of the Queensland continental margin Sites 821, 820, 819, and 822.

Table 1. Summary of penetration data.

\begin{tabular}{lccc}
\hline Hole & Water depth $(\mathrm{m})$ & Penetration (mbsf) & Oldest sediments \\
\hline $821 \mathrm{~A}$ & 212.7 & 400.0 & early Pleistocene \\
$820 \mathrm{~B}$ & 279.0 & 400.0 & early Pleistocene \\
$819 \mathrm{~A}$ & 565.2 & 400.0 & early Pleistocene \\
$822 \mathrm{~A}$ & 955.2 & 433.9 & late Pliocene \\
\hline
\end{tabular}

between $\mathrm{CN} 15$ and $\mathrm{CN} 14 \mathrm{a}$. Overall, the sampling resolution for $\mathrm{X}$-ray diffraction (XRD) and the precision of the biostratigraphy does not permit further correlations to be made at this time.

\section{METHODS}

Pore fluids were obtained from 5-cm whole-round cores as described by Davies, McKenzie, Palmer-Julson, et al. (1990) and squeezed at a rate of one sample per core according to conventional methods (Manheim and Sayles, 1974). All interstitial-water measurements other than carbon and oxygen isotopes were performed on board the Resolution and have been reported previously. The data discussed in this study include alkalinity, sulfate, $\mathrm{Mg}^{2+}, \mathrm{Ca}^{2+}$, and $\mathrm{Sr}^{2+}$ (Table 3). Also included are data on the concentration of methane (originally published in the Leg 133 Initial Reports volume, Davies, McKenzie, Palmer-Julson, et al., 1991). Samples for DIC $\delta^{13} \mathrm{C}$ analyses were filtered with a $0.2-\mu \mathrm{m}$ filter, poisoned with $\mathrm{HgCl}_{2}$, and stored in sealed $5-\mathrm{cm}^{3} \mathrm{am}$ pules until the time of analysis. Samples for $\delta^{18} \mathrm{O}$ analyses were stored in a similar manner, with the exception that samples were not treated with $\mathrm{HgCl}_{2}$.

Using the interstitial-water sample squeezed cakes, the sediment was disaggregated and sieved to obtain the $<63 \mu \mathrm{m}$ fraction. The dolomite in this fraction then was concentrated using selective leaching in buffered acetic acid. The concentration of the dolomite in the separate was continually monitored using XRD until a sample of $>95 \%$ dolomite was obtained. The samples were examined using scanning electron microscopy (SEM) and analyzed for their stable carbon and oxygen isotopic compositions. The $\mathrm{CO}_{2}$ from the DIC in the pore waters was extracted by acidification under vacuum. Carbonate samples were reacted in phosphoric acid at $90^{\circ} \mathrm{C}$ for $10 \mathrm{~min}$ (Swart et al., 1991). The oxygen isotopic composition of the water was measured by equilibrating $\mathrm{CO}_{2}$ with the sample, using the standard methods of Epstein and Mayeda (1957).

The $\mathrm{CO}_{2}$ produced in all reactions was analyzed using a FinniganMAT 251, and these data were corrected for the usual isobaric inter- 


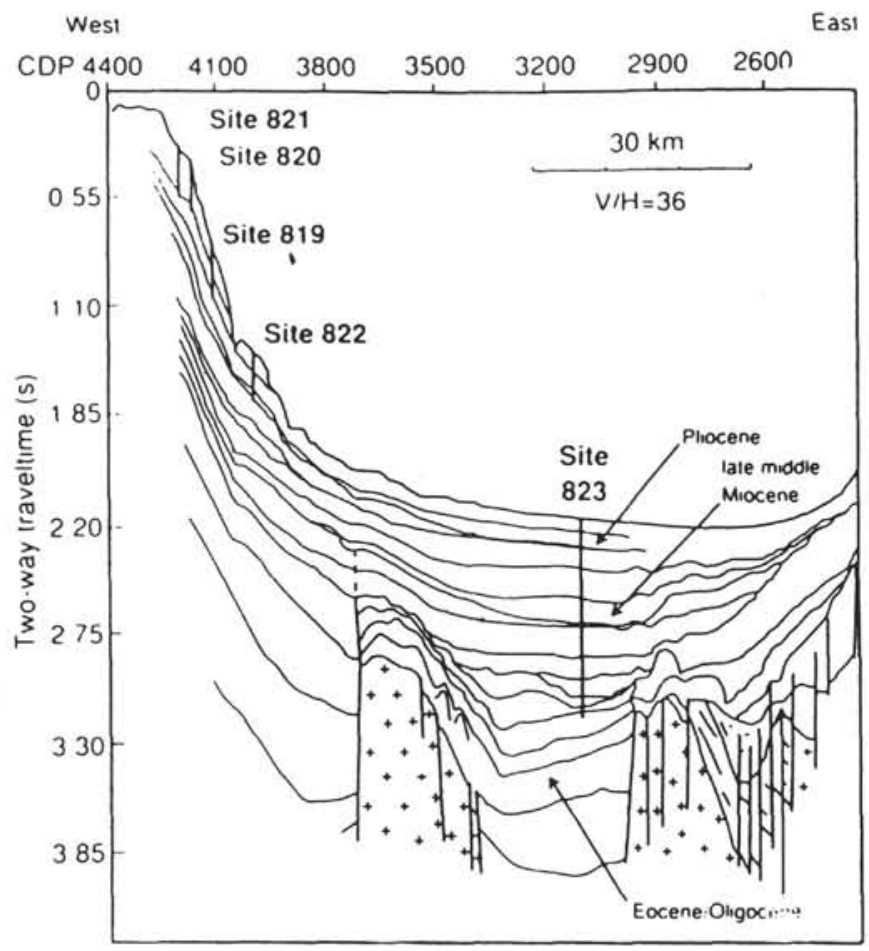

Figure 2. Schematic section of Sites 819 to 823 from the continental margin across the Queensland Trough.

Table 2. Summary of calcareous nannofossil data.

\begin{tabular}{|c|c|c|c|c|}
\hline $\begin{array}{l}\text { Nanno- } \\
\text { fossil } \\
\text { zone }\end{array}$ & $\begin{array}{c}\text { Site } 819 \\
\text { Depth (mbsf) }\end{array}$ & $\begin{array}{c}\text { Site } 820 \\
\text { Depth (mbsf) }\end{array}$ & $\begin{array}{c}\text { Site } 821 \\
\text { Depth (mbsf) }\end{array}$ & $\begin{array}{c}\text { Site } 822 \\
\text { Depth (mbsf) }\end{array}$ \\
\hline CNIS & $18.5-27.5$ & $27.2-36.7$ & $13.9-23.4$ & $10.4-19.9$ \\
\hline $\mathrm{CN} 14 \mathrm{~b}$ & Missing & $93.7-103.2$ & $108.9-118.4$ & Missing \\
\hline $\mathrm{CN} 14 \mathrm{a}$ & $37.0-46.5$ & $122.2-131.7$ & $222.6-232.4$ & $182.6-192.2$ \\
\hline $\mathrm{CN} 13 \mathrm{~b}$ & Base & Base & Base & $288.4-298.1$ \\
\hline
\end{tabular}

ferences. The oxygen isotopic compositions of the dolomite have been corrected using an $\alpha$ value of 1.0087 (P.K. Swart, unpubl. data) for fractionation of oxygen between $\mathrm{CO}_{2}$ and dolomite at $90^{\circ} \mathrm{C}$.

\section{RESULTS}

\section{Pore-water Chemistry}

\section{Summary of Previous Data}

The changes in pore-water chemistry have been discussed previously (Davies, McKenzie, Palmer-Julson, et al., 1990) and also are extensively discussed by Swart et al. (this volume). At all sites examined, the concentration of $\mathrm{SO}_{4}{ }^{2-}$ in the interstitial pore waters decreases from surface seawater concentrations of approximately 28 $\mathrm{mM}$ to zero with increasing depth (Table 3 ). The depth at which this complete depletion occurs decreases with distance away from the platform edge (Figs, 4C, 5C, and 6C). For example, at Site 821, the closest site to the continental margin, $\mathrm{SO}_{4}{ }^{2-}$ is not completely exhausted until $150 \mathrm{mbsf}$, whereas at Site 822 , it has been used up at a depth of 20 mbsf. This decrease in sulfate concentration is accompanied by a small increase in alkalinity and dramatic decreases in $\mathrm{K}^{+}$ $(10-4 \mathrm{mM}), \mathrm{Mg}^{2+}(55-10 \mathrm{mM})$, and $\mathrm{Ca}^{2+}(10-3 \mathrm{mM})$ and an increase in $\mathrm{Sr}^{2+}(98-800 \mu \mathrm{M})$ and $\mathrm{Na}^{2+}(460-520 \mathrm{mM})$ (Fig. 7). The magnitude of the changes in all these elements is related to the water depth and the position that the core was taken relative to the platform margin. Generally, the largest percentage increase and decrease occurred in

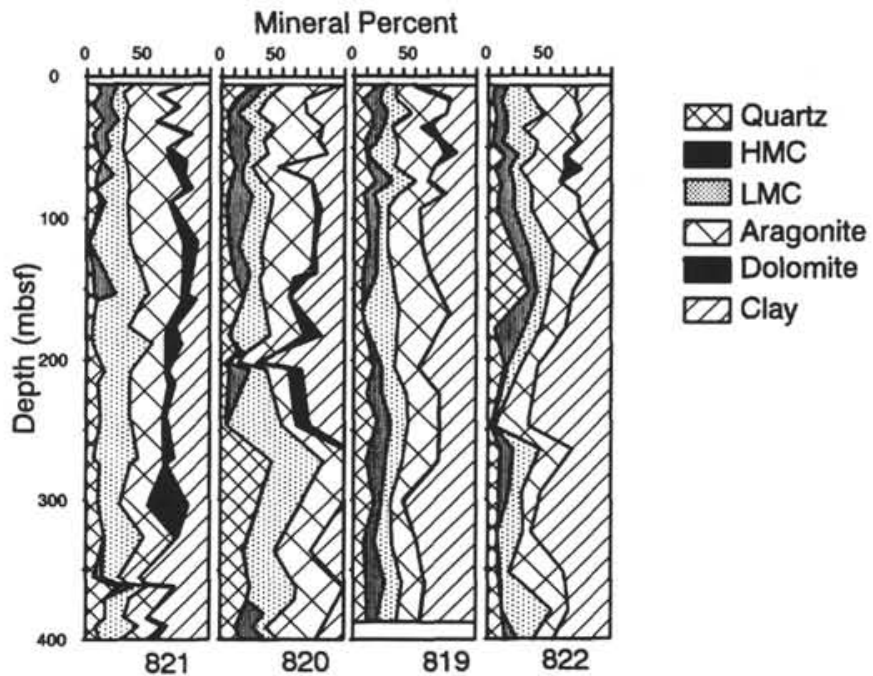

Figure 3. X-ray mineralogy of Sites 819 to 823 , as determined on board the JOIDES Resolution. Using the percentage of carbonate, the relative percentages of quartz, clay, LMC, HMC, aragonite, and dolomite were determined.

the cores closest to the margin, decreasing offshore. Large increases in the concentration of methane are coincident with the depletion of sulfate in the interstitial pore fluids (Figs. 4C, 5C, and 6C). The concentration of organic material in all the sediments is low $(<0.5 \%)$, although there is a tendency for proximal sites to have lower concentrations and higher $\mathrm{C} / \mathrm{N}$ ratios than distal ones (Davies, McKenzie, and Palmer-Julson, et al., 1991).

\section{Distribution of Dolomite}

The concentration of dolomite in the four studied cores decreases with increasing distance from the continental shelf margin (Table 3 ). At Site 821, that nearest the margin, dolomite is ubiquitous throughout the core; at Site 820, dolomite is predominantly located between 50 and $300 \mathrm{mbsf}$, while at Sites 819 and 822 , dolomite is restricted to an interval between 20 and 80 mbsf. At Sites 821 and 820 , the concentration is inversely correlated with the concentration of HMC (Figs. $4 \mathrm{~B}, 5 \mathrm{~B}$, and 6B). At Sites 819 and 822, the main concentrations of dolomite are associated with a disconformity of approximately 190 k.y. at 34 and 65 mbsf, respectively. Minor amounts of dolomite also were described by shipboard sedimentologists, but were not detected using XRD. Under the SEM, the dolomite crystals from all sites appear similar in size and appearance to other deep-sea dolomites (Mullins et al., 1984; Swart and Guzikowski, 1988). The crystals are between 5 and $10 \mu \mathrm{m}$ in size, are not abraded, and are intimately associated with aragonite needles (Figs. 8A and 8B).

\section{Pore-water Carbon and Oxygen Isotopic Data}

Profiles of the carbon isotopic composition of the pore fluids from Sites 819, 820, and 821 are shown in Figures 4A, 5A, and 6A. All three sites show a depletion in the $\delta^{13} \mathrm{C}$ in the pore-water DIC in the upper $50 \mathrm{mbsf}$ and indicate values between -1 and $+1 \%$ throughout the remainder of the cores. The greatest depletion occurs at Site 819, where values as low as $-15 \%$ were measured. In contrast, at Sites 821 and 820 , the $\delta^{13} \mathrm{C}$ of the DIC only attains a value of approximately $-7 \%$. The average $\delta^{13} \mathrm{C}$ of the DIC at Site 820 is slightly lower than those at Sites 819 and 821 .

The oxygen isotopic composition of the pore waters is heavier in the upper $100 \mathrm{mbsf}$ and reaches a maximum value of $+1.5 \%$ in Sites 819 and 821 (Fig. 9). These values become isotopically depleted at all sites with increasing depth. The magnitude of the depletion is greatest at Site 822 and least at Site 821 . 


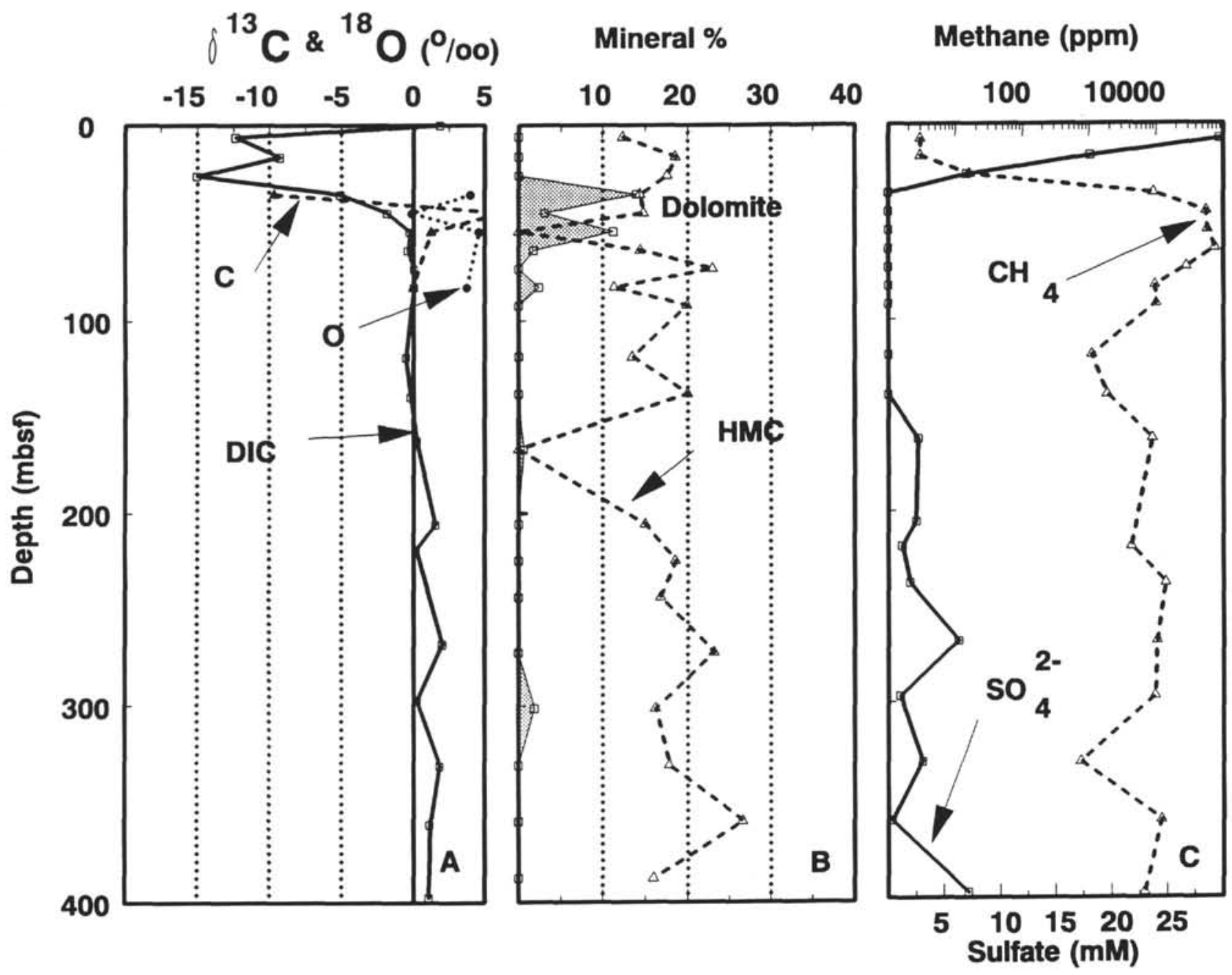

Figure 4. A. The $\delta^{13} \mathrm{C}$ of the DIC and the $\delta^{13} \mathrm{C}$ and $\delta^{18} \mathrm{O}$ of the dolomite as a function of depth at Site 819. B. Comparison of the abundance of HMC and dolomite, Site 819. C. Interstitial profiles of the dissolved sulfate and methane concentration from Site 819.

\section{Dolomite Carbon and Oxygen Isotopic Data}

The $\delta^{13} \mathrm{C}$ value of the dolomites varies between +1 and $-10 \%$, with the most depleted value occurring at Site 819 (Figs. 4A, 10 and $11)$. With only a few exceptions, the average $\delta^{13} \mathrm{C}$ value of the dolomites was approximately $1.75 \%$ heavier than the $\delta^{13} \mathrm{C}$ of the associated DIC (Fig. 10). The $\delta^{18} \mathrm{O}$ of the dolomite in the upper portion of the core is significantly depleted relative to dolomites that formed deeper in the core (Figs. 4A, 5A, 6A, and 12).

\section{DISCUSSION}

\section{Profiles of the Carbon Isotopic Composition of the DIC}

One of the more surprising results of this study is that the $\delta^{13} \mathrm{C}$ of the pore water does not reflect the processes of sulfate reduction and methanogenesis, which either have taken place or are currently taking place in the sediments. For example, at Site 821 the sulfate decreases to zero by $150 \mathrm{mbsf}$ yet the $\delta^{13} \mathrm{C}$ only decreases to -4.93 at 30.85 mbsf, significantly above the zone of maximum sulfate depletion. Similarly, even though an abundance of methane is produced below the sulfate reduction zone, the $\delta^{13} \mathrm{C}$ never becomes heavier than $+2 \%$. Previous studies have shown that the $\delta^{13} \mathrm{C}$ of the DIC responds to the oxidation of organic material by sulfate-reducing bacteria, producing highly depleted $\delta^{13} \mathrm{C}$ values and to the process of methanogenesis by producing highly enriched $\delta^{13} \mathrm{C}$ (Presley and Kaplan, 1968; Nissen- baum et al., 1972; and others). In addition, such signatures have been frequently recognized in ancient rocks (Irwin et al., 1977). In this study, the most depleted $\delta^{13} \mathrm{C}$ values for the DIC are found at Site 819, the site with the shallowest transition between the sulfate reduction and methanogenesis zone. Throughout the remainder of the core, the $\delta^{13} \mathrm{C}$ of the DIC becomes slightly heavier only attaining values of $+2 \%$. There is no evidence of any isotopically enriched $\delta^{13} \mathrm{C}$ signatures higher than $+2 \%$. At the sites closer to the Queensland coast, similar trends were observed, although the magnitude of depletion of $\delta^{13} \mathrm{C}$ is not as great in the upper portion of the cores. The absence of a $\delta^{13} \mathrm{C}$ signature in the pore waters at depths greater than $20 \mathrm{mbsf}$ in spite of the large sulfate depletion suggests that the isotopic composition of the carbonate system is being heavily buffered and that the eventual carbon isotopic composition of the DIC is controlled by the dissolution of the precursor carbonate, rather than the influx of isotopically exotic (light from sulfate reduction and heavy from methanogenesis) $\mathrm{CO}_{2}$. Evidence for the precipitation of calcium carbonate as well as other reactions involving carbon is provided by other pore-water data and has been discussed previously (Davies, McKenzie, Palmer-Julson, et al., 1991; Swart et al., this volume). These studies show large-scale removal of $\mathrm{HCO}_{3}{ }^{-}, \mathrm{Ca}^{2+}$, and $\mathrm{Mg}^{2+}$ from the pore waters. These depletions and excesses can be explained by the following reactions.

The addition of $\mathrm{CO}_{2}$ lowers the saturation with respect to calcium carbonate promoting the dissolution of $\mathrm{CaCO}_{3}$, which in turn raises 
Table 3. Pore-water chemical data, mineralogy, $\delta^{13} \mathrm{C}$ (DIC), $\delta^{13} \mathrm{C}$, and $\delta^{18} \mathrm{O}$ data for dolomites and $\delta^{18} \mathrm{O}$ fluids.

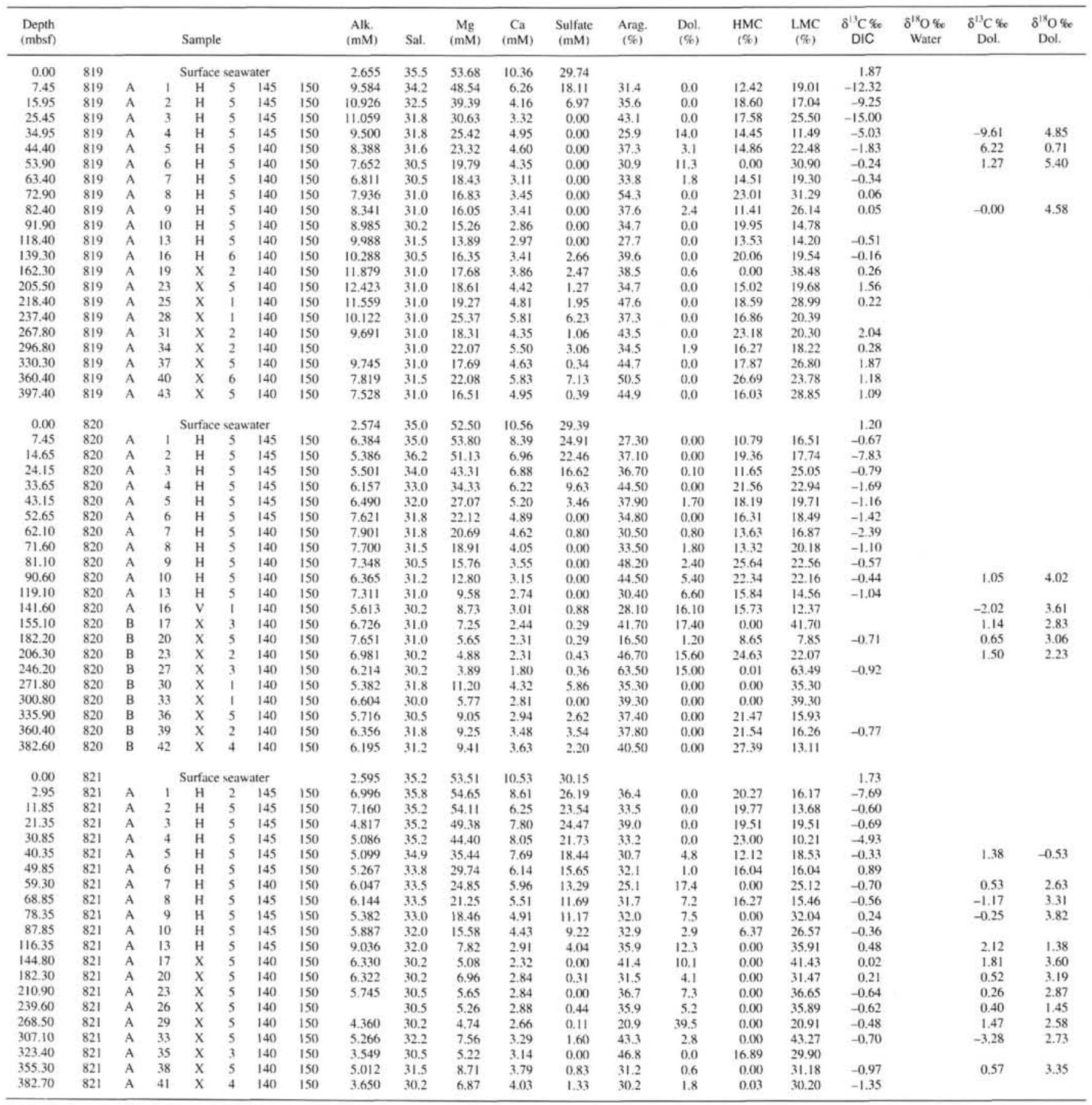

the alkalinity. The addition of carbonate from the dissolution of more soluble carbonate minerals raises saturation with respect to the less soluble minerals (such as LMC and dolomite) and, hence, causes precipitation to take place.

Dissolution and precipitation can also be governed by so-called mineralogic control. In this type of mechanism, the system is driven by the relative differences in solubility between LMC and aragonite and HMC. Once the system initially becomes undersaturated with respect to either aragonite or $\mathrm{HMC}$, these minerals start to dissolve. However, the dissolution drives the system toward greater oversaturation with respect to $\mathrm{LMC}$; hence, this mineral precipitates, while aragonite and $\mathrm{HMC}$ dissolve. As long as less stable minerals are present, no additional $\mathrm{CO}_{2}$ needs to be added to the system to maintain undersaturation. In such a case, the carbon isotopic composition of the pore fluids should be dominated by the isotopic composition of the precursor carbonate, not by the carbon isotopic composition of the oxidized organic material. Further confirmation of the high rates of carbonate recrystallization at Sites 820 and 821 is provided by the profiles of dissolved $\mathrm{Sr}^{2+}$ (Fig. 8).

To test this theory, it is possible to estimate the change in the $\mathrm{pCO}_{2}$ as a result of the influx of $\mathrm{CO}_{2}$ produced during sulfate reduction. If the isotopic composition of the organic material is assumed to be $-15 \%$, then the isotopic composition of the DIC can be estimated. In a closed system having a porosity of approximately $50 \%$, one may estimate that the $\mathrm{pCO}_{2}$ will increase to 0.1 should all the sulfate be oxidized using the stoichiometry depicted by Equation 1. The results 


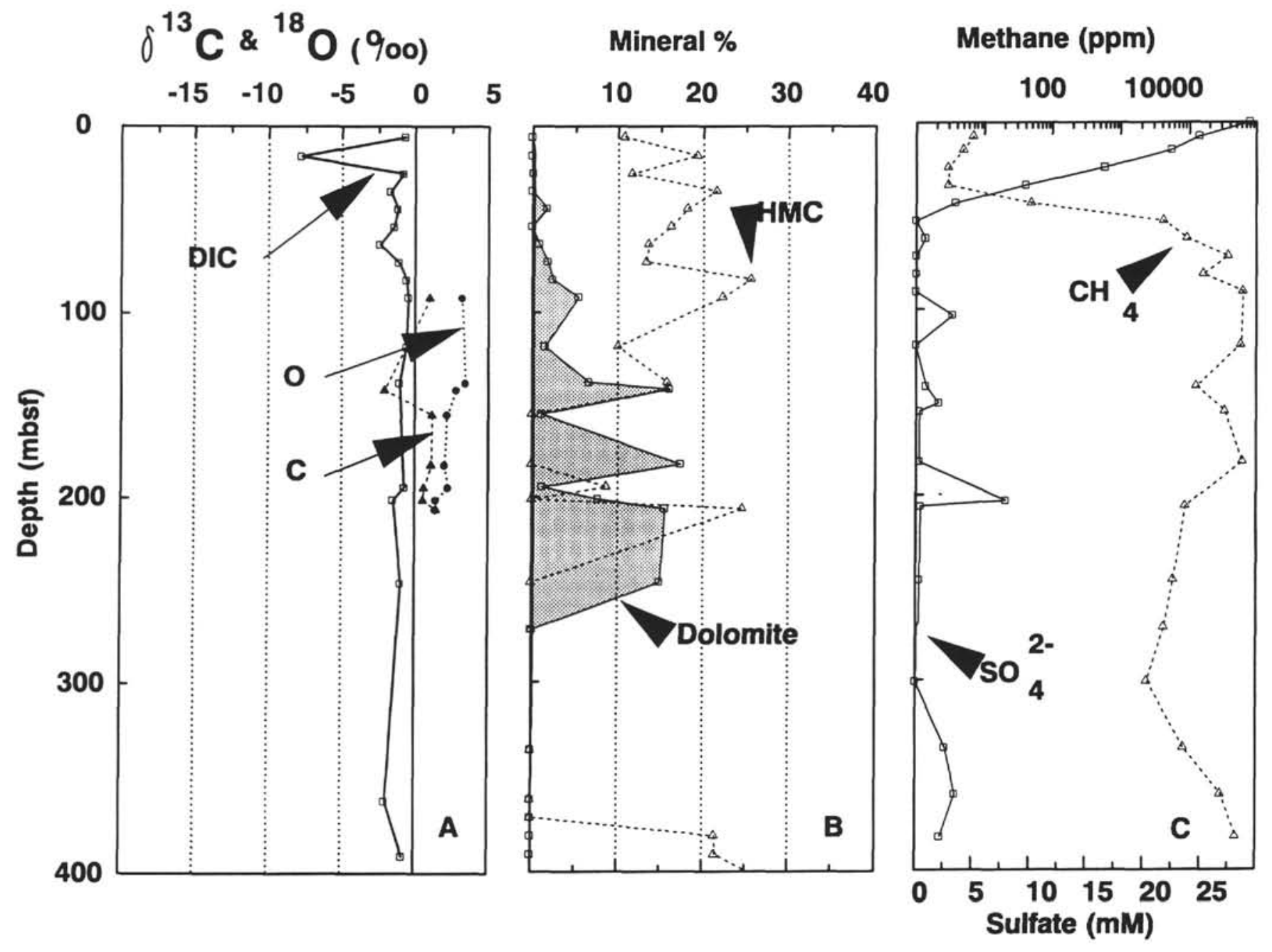

Figure 5. A. The $\delta^{13} \mathrm{C}$ of the DIC and the $\delta^{13} \mathrm{C}$ and $\delta^{18} \mathrm{O}$ of the dolomite as a function of depth at Site 820. B. Comparison of the abundance of $\mathrm{HMC}$ and dolomite, Site 820. C. Interstitial profiles of the dissolved sulfate and methane concentration from Site 820 .

from this calculation show that the $\delta^{13} \mathrm{C}$ of the DIC only decreases at most to $-2 \%$. This value is not significantly different from what was actually measured in this study. The fact the $\delta^{13} \mathrm{C}$ of the DIC at Site 820 is slightly more depleted than at Site 819 or 821 might be expected if, as suggested by the shipboard reports, this site contains a greater proportion of terrestrial organic material that initially contains a more depleted carbon isotopic value than marine organic carbon.

\section{Origin of the Dolomites}

Evidence from SEM photomicrographs clearly suggests that the dolomites are not detrital in origin, but rather formed as authigenic precipitates and/or replacements of the primary carbonate minerals. The morphology and the replacive nature of these dolomites is similar to dolomites studied in other periplatform sediments (Mullins et al., 1984; Swart and Guzikowski, 1985). Mullins et al. (1984) suggested that the dolomites which they studied in sediments north of Little Bahamas Bank formed in situ, perhaps in response to fluid movement through the sediments. In a similar study, Swart and Guzikowski (1988) concluded that the dolomites formed close to the seawater/ sediment interface, with the $\mathrm{Mg}^{2+}$ being derived principally from the dissolution of $\mathrm{HMC}$ and with additional $\mathrm{Mg}^{2+}$ being supplied from the interstitial pore fluid and by diffusion from overlying seawater.

One aspect of the dolomite occurrence that cannot be explained is its higher concentration in sediments closer to the continental margin.
All sites appear to have similar sedimentation rates, physical properties (permeability and porosity), similar concentrations of organic material, and sufficient concentrations of HMC. The present distribution of dolomite does not appear to be related to the presence or absence of sulfate in the sediments, as has been previously suggested (Baker and Kastner, 1981). In fact, higher concentrations of dolomite occur at Site 821, where the sulfate is not completely depleted until a depth of 150 mbsf. It is true that at Sites 819 and 820 dolomite is not present in the sediments until the sulfate is exhausted, but it is only localized to a small interval and the vast majority of the core that contains no sulfate also contains no dolomite, yet does contain abundant HMC.

Further information about the formation of the dolomite in this study is provided by comparing the $\delta^{13} \mathrm{C}$ and $\delta^{18} \mathrm{O}$ of the dolomite with the $\delta^{13} \mathrm{C}$ of the DIC and the temperature and $\delta^{18} \mathrm{O}$ of the pore fluid. If all the dolomites contain depleted $\delta^{13} \mathrm{C}$ values, then this might suggest that these dolomites formed at the same depth relative to the seafloor and have ended up at their present position as a result of continued sedimentation. However, in most instances, the $\delta^{13} \mathrm{C}$ of the dolomite is close to that of the present-day DIC (Fig. 10). In addition, with the exception of the dolomites in the upper $50 \mathrm{mbsf}$, the $\delta^{18} \mathrm{O}$ of these dolomites decreases with increasing depth (Fig. 13). The magnitude of these depletions corresponds approximately to the decrease that might be expected as a result of recrystallization in the present geothermal gradient and is in excess of changes seen in the pore-water 


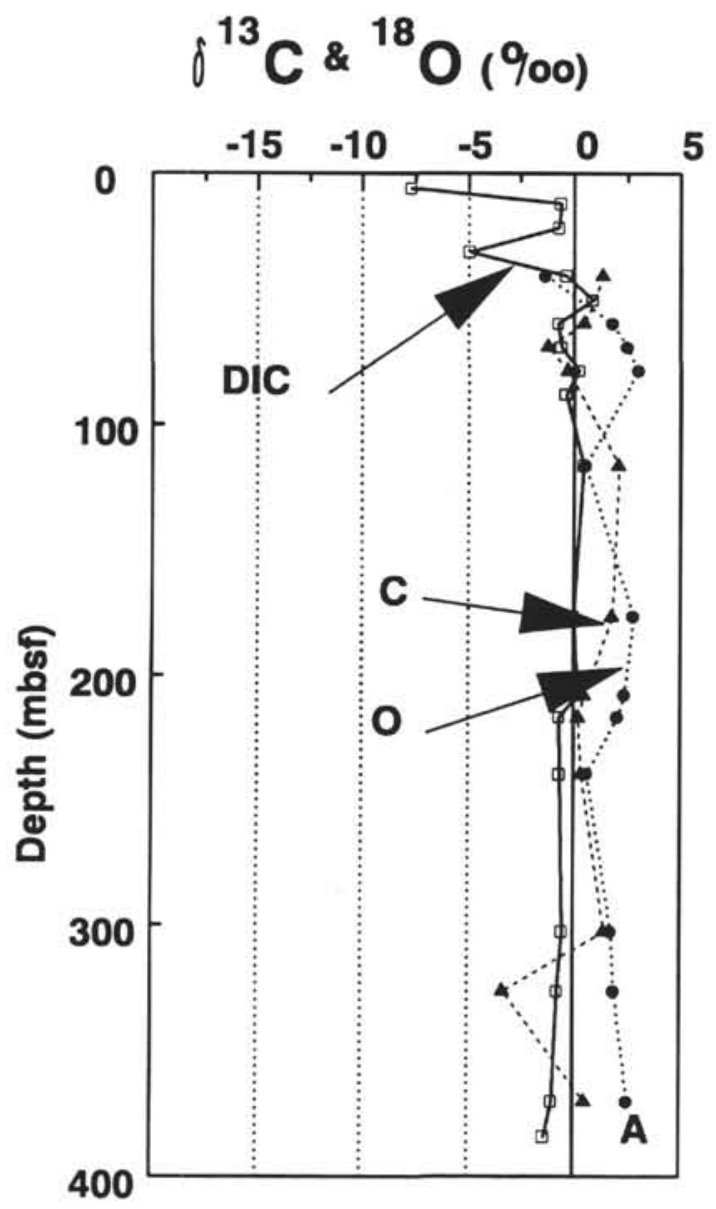

\section{Mineral \%}

5

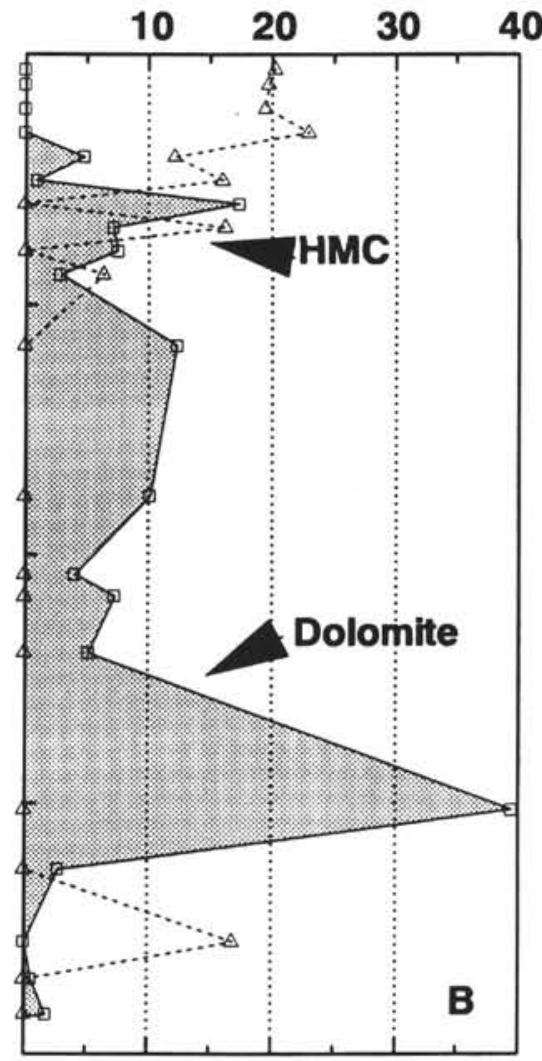

Methane (ppm)

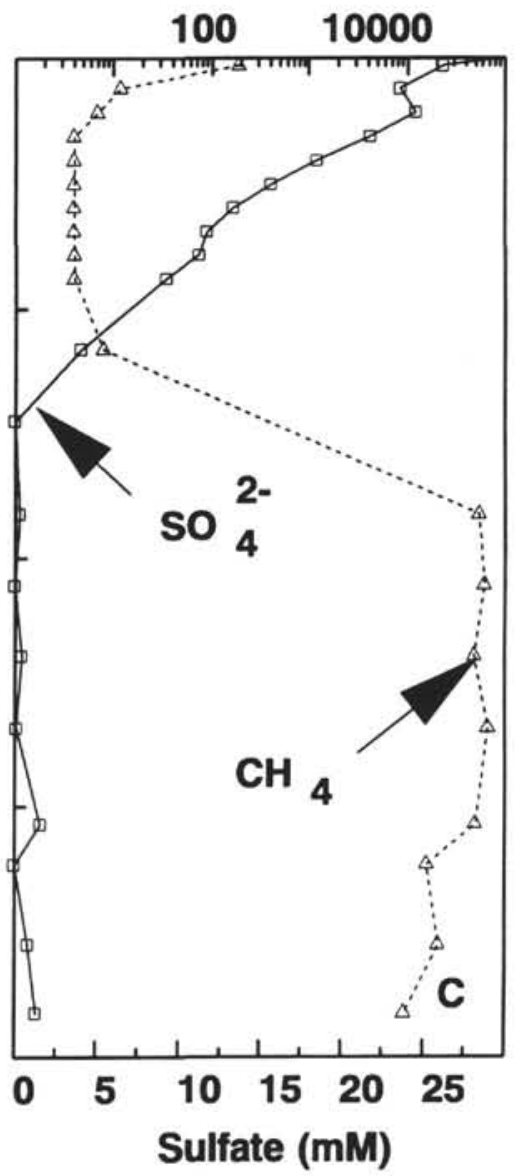

Figure 6. A. The $\delta^{13} \mathrm{C}$ of the DIC and the $\delta^{13} \mathrm{C}$ and $\delta^{18} \mathrm{O}$ of the dolomite as a function of depth at Site 821. B. Comparison of the abundance of $\mathrm{HMC}$ and dolomite, Site 821. C. Interstitial profiles of the dissolved sulfate and methane concentration from Site 821.

$\delta^{18} \mathrm{O}$ (Fig. 7). Two possible explanations can be offered for the variation in the $\delta^{18} \mathrm{O}$ of the dolomite seen in the upper portion of the cores. First, these dolomites may still contain remnant chemical signatures from their precursors. With increasing depth, continued recrystallization may remove this signature. A second possibility is that these dolomites formed in the presence of waters having variable $\delta^{18} \mathrm{O}$. The pore fluids from the upper $100 \mathrm{mbsf}$ do show a high degree of variability, which probably relates to the original variation in the water buried with the sediment during glacial and interglacial periods.

These data suggest one of the following hypotheses: (1) the dolomites formed from the present pore fluids and continue to form at the present time or (2) the dolomites formed at an earlier time and are undergoing a process of continual recrystallization and equilibrium with their pore fluids.

Although evidence is based on SEM observations, I have been unable to document dolomite replacing HMC, and, in fact, the SEM micrographs show that dolomite predominantly replaces aragonite rather than $\mathrm{HMC}$; the inverse relationship between the concentrations of HMC and dolomite at Sites 820 and 821 suggests that these dolomites formed from the alteration of HMC. As an example of the amount of dolomite which might be formed from the alteration of HMC a typical sediment having $20 \mathrm{wt} \%$ of $\mathrm{HMC}$ containing $20 \mathrm{~mol} \%$ $\mathrm{Mg}$ can be considered. If all the $\mathrm{Mg}$ is released by dissolution, then only $4 \mathrm{wt} \%$ dolomite could be produced. This is approximately the average amount of dolomite found at all sites, although in some instances concentrations as high as $37 \%$ were reached. Higher concentrations could be produced if the initial concentration of HMC in the sediments was also greater. The only other sources that might provide $\mathrm{Mg}^{2+}$ are diffusion from the overlying seawater and from the ambient pore water; supply of $\mathrm{Mg}^{2+}$ from advection is ignored as a result of the steep geochemical gradients present. Both these latter two sources are simply too small to provide sufficient quantities of $\mathrm{Mg}^{2+}$. If the source of $\mathrm{Mg}^{2+}$ is predominantly the dissolution of $\mathrm{HMC}$ and the dolomite is inversely correlated with abundance of $\mathrm{HMC}$, then significant amounts of dolomite cannot be forming at the present time in the areas where no $\mathrm{HMC}$ is present. For example, at Site 821 there is apparently no HMC between 150 and 340 mbsf. If dolomite is presently forming here, it must be utilizing the $\mathrm{Mg}^{2+}$ in the pore fluids. However, at this site the maximum gradient is between the sediment/water interface and $144.35 \mathrm{mbsf}$. This depth also corresponds to the disappearance of HMC and with the exception of one sample at $300 \mathrm{mbsf}$, the depth at which dolomite is the most abundant mineral in the core. Below $144.35 \mathrm{mbsf}$, as there is no $\mathrm{HMC}$ or any $\mathrm{Mg}^{2+}$ gradient one can conclude that probably no significant dolomite formed either as a result of the dissolution of $\mathrm{HMC}$ or diffusion of $\mathrm{Mg}^{2+}$ from above. At Site 820 , a similar pattern is present, with the minimum $\mathrm{Mg}^{2+}$ concentration occurring at 206.35 mbsf, approximately coincident with the disappearance of HMC and the maximum abundance of dolomite. Hence, the isotopic equilibrium between the dolomite and the pore waters must either be coincidence or the dolomite is continually re-equilibrating and recrystallizing. The 


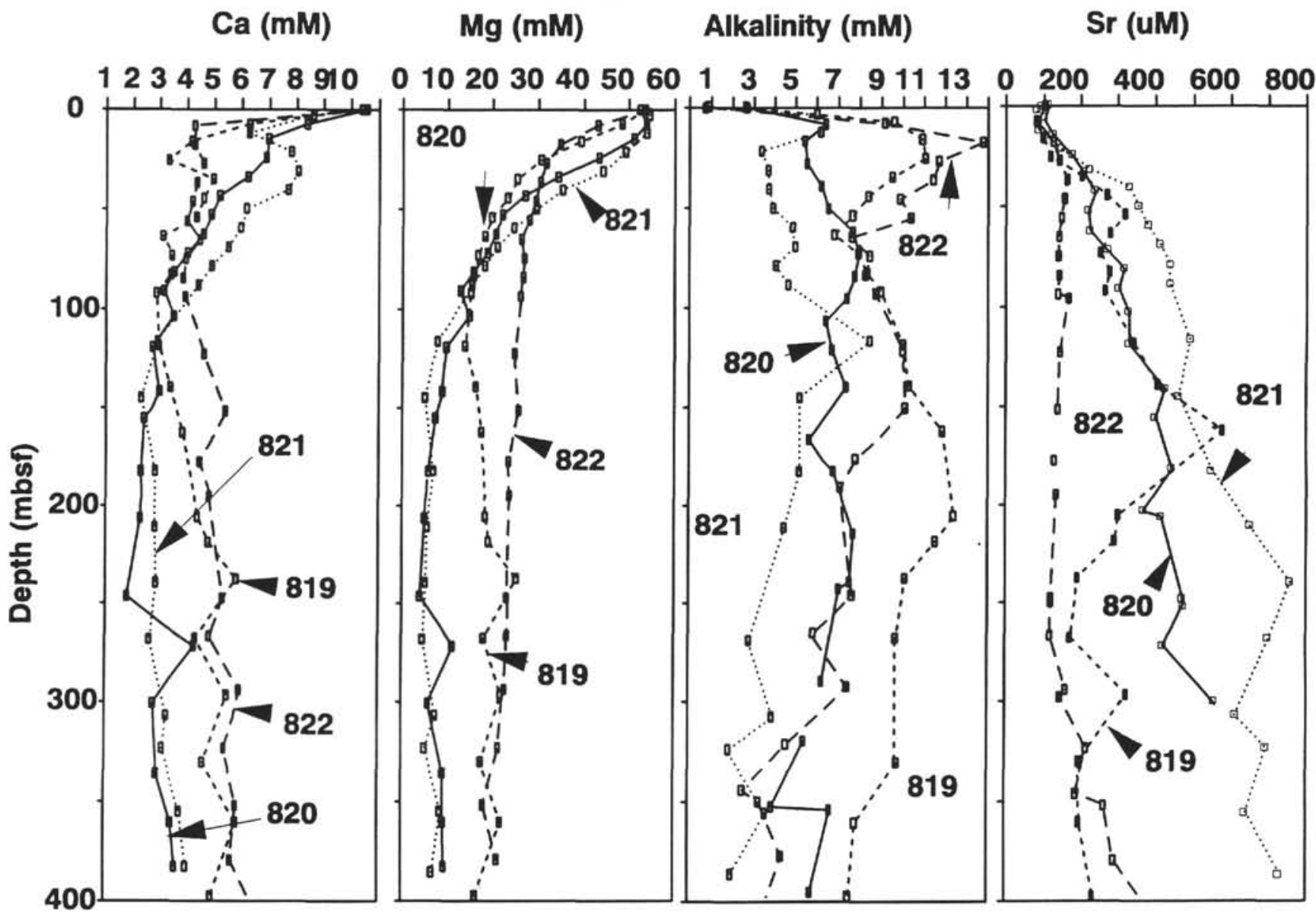

Figure 7. Summary of interstitial pore-water concentrations of $\mathrm{Ca}^{2+}, \mathrm{Mg}^{2+}$, alkalinity, and $\mathrm{Sr}^{2+}$ from Sites 819 to 822 .

process of re-equilibration need not necessarily involve solid-state processes, but could conceivably be a process of dissolution of small $(<1 \mu \mathrm{m})$ dolomite crystals and the nucleation of larger ones. Although there is direct evidence of this process, dolomite rhombs do appear to range in size from $<1$ to $10 \mu \mathrm{m}$ in size (Fig. 9B).

Sites 819 and 822 exhibit different patterns of dolomite distribution. First, although dolomite occurs in minor amounts throughout the cores, most is concentrated below a disconformity surface, suggesting that the dolomite formed in association with a period of nondeposition. Second, the top of the dolomite occurrence at both these sites corresponds approximately to the base of the sulfate reduction zone. Third, Site 819 was the only site to show significant depletions in the $\delta^{13} \mathrm{C}$ of the DIC (no samples for DIC have been measured from Site 822 ), and the dolomites at Site 819 also recorded a depleted $\delta^{13} \mathrm{C}$ signature. Fourth, at both these sites, the concentration of dolomite is not related to the absence of HMC. One may suggest that the formation of dolomite at Sites 819 and 822 is not related to the dissolution of HMC, but instead to the period of nondeposition between 0.265 and $0.465 \mathrm{Ma}$. During this time, intense sulfate reduction caused dissolution and an increase in alkalinity in the sediments. This promoted the formation of dolomite, with the $\mathrm{Mg}^{2+}$ being supplied by diffusion from the surface. This episode did not take place at Sites 820 and 821 , as these areas did not experience a hiatus in deposition.

\section{CONCLUSIONS}

The interstitial pore-water profiles from Sites 819 to 822 show clear evidence of extensive sulfate reduction and methanogenesis; however, the expected carbon isotopic signatures associated with these process were largely absent. Similarly, diagenetic dolomites that formed within these sequences did not contain any evidence of carbon isotopic signatures associated with these zones even though they were clearly formed or are forming at the present time within these zones. The explanation for the absence of such signatures in these pore fluids and dolomites formed from the same pore waters appears to lie in the fact that the sediments contain a high percentage of calcium carbonate, which is buffering the influx of $\mathrm{CO}_{2}$ derived from the processes of sulfate reduction and methanogenesis. Here, I suggest that the interpretation of zones of organic carbon diagenesis in ancient rocks must be treated with caution, especially in situations where the sediment was originally composed of a significant proportion of calcium carbonate.

Finally, the data presented here suggest that there may be a process of continued recrystallization and re-equilibration between the pore water and the dolomites. Hence, the present isotopic signatures in the dolomites do not necessarily reflect the chemical conditions under which these dolomites formed, but merely the present conditions in the core.

\section{ACKNOWLEDGMENTS}

The author thanks the technicians, scientists, and crew of Leg 133 for continued help throughout the cruise. Joe Powers, Joe DeMorett, and Scott Chaffey especially are thanked for their help in the chemistry laboratory. Alex Isern, Danny Muller, and Judy McKenzie provided friendship and discussion throughout. The manuscript was improved by reviews from Paul Baker and Jim Lawrence, although not necessarily agreeing with the ideas expressed in this study. Help with the analyses was provided by Amel Saied, Jim Leder, Jeff Abell, Michel Lopez, and Phil Kramer. 


\section{REFERENCES $^{*}$}

Baker, P.A., and Burns, S.J., 1985. Occurrence and formation of dolomite in organic-rich continental margin sediments. AAPG Bull., 69:1917-1930.

Baker, P.A., and Kastner, M., 1981. Constraints on the formation of sedimentary dolomite. Science, 213:215-216.

Burns S.J., and Baker, P.A., 1987. A geochemical study of dolomite in the Monterey formation, California. J. Sediment. Petrol., 57:128-139.

Burns, S.J., Baker, P.A., and Showers, W.J., 1988. The factors controlling the formation of dolomite in organic-rich sediments: Miocene Drakes Bay formation, California. In Sedimentology and Geochemistry of Dolostones. Spec. Publ.-Soc. Econ. Paleontol. Mineral., 43:41-52.

Claypool, G.E., and Kaplan, I.R., 1974. The origin and distribution of methane in marine sediments. In Kaplan, I.R. (Ed.), Natural Gases in Marine Sediments: New York (Plenum), 99-140.

Compton, J.S., and Siever, R., 1986. Diffusion and mass balance of Mg during early dolomite formation, Monterey Formation. Geochim. Cosmochim. Acta, 50:125-135.

Davies, P.J., McKenzie, J.A., Palmer-Julson, A., et al., 1991. Proc. ODP, Init. Repts., 133: College Station, TX (Ocean Drilling Program),

Epstein, S., and Mayeda, T., 1953. Variation of ${ }^{18} \mathrm{O}$ content of waters from natural sources. Geochim. Cosmochim. Acta, 42:213-224.

Friedman, I., and Murata, K.J., 1979. Origin of dolomite in Miocene Monterey shale and related formations of the Temblor Range, California. Geochim. Cosmochim. Acta, 43:1357-1365.

Irwin, H., Curtis, C.D., and Coleman, M., 1977. Isotopic evidence for source of diagenetic carbonates formed during burial of organic-rich sediments. Nature, 269:209-213.

Kastner, M., Elderfield, H., Martin, J.B., Suess, E., Kvenvolden, K.A., and Garrison, R.E., 1990. Diagenesis and interstitial-water chemistry at the Peruvian continental margin - major constituents and strontium isotopes. In Suess, E., von Huene, R., et al., Proc. ODP. Sci. Results, 112: College Station, TX (Ocean Drilling Program), 413-440.

Kelts, K., and McKenzie, J.A., 1982. Diagenetic dolomite formation in Quaternary anoxic diatomaceous muds of Deep Sea Drilling Project Leg 64 . Gulf of California. In Curray, J.R., Moore, D.G., et al., Init. Repts. DSDP, 64 (Pt.2): Washington (U.S. Govt. Printing Office), 553-569.

Land, L.S., 1985. The origin of massive dolomite. J. Geol. Educ., 33:112-125.

Machel, H.G., and Mountjoy, E.W., 1986. Chemistry and environments of dolomitization-a reappraisal. Earth-Sci. Rev., 23:175-222.
Manheim, F.T., and Sayles, F.L., 1974. Composition and origin of interstitial waters of marine sediments based on deep sea drill cores. In Goldberg. E.D. (Ed.), The Sea (Vol. 5): New York (Wiley Interscience), 527-568.

Mullins, H.T., Heath, K.C., Van Buren, M., and Newton K., 1984. Anatomy of a modern open-oceanic carbonate slope: northern Little Bahama Bank. Sedimentology, 31:141-168.

Nissenbaum, A., Presley, B.J., and Kaplan, I.R., 1972. Early diagenesis in a reducing fjord, Saanich Inlet, British Columbia, I. Chemical and isotopic changes in major components of interstitial water. Geochim. Cosmochim. Acta, 36:1007-1027.

Pisciotto, K.A., 1981. Review of secondary carbonates in the Monterey formation, California. In The Monterey Formation and Related Siliceous Rocks of California. Spec. Publ.-Soc. Econ. Mineral. Paleontol., 273-283.

Pisciotto, K.A., and Mahoney, J.J., 1981. Isotopic survey of diagenetic carbonates, Deep Sea Drilling Project, Leg 63. In Yeats, R.S., Haq., B.U., et al., Init. Repts. DSDP, 63: Washington (U.S. Govt. Printing Office), 595-609.

Prasad, S., 1985. Microsucrosic dolomite from the Hawthorn formation (Miocene) of Florida: distribution and development [M.S. thesis]. Univ. of Miami.

Presley, B.J., and Kaplan, I.R., 1968. Changes in dissolved sulfate, calcium and carbonate from interstitial water of near shore sediments. Geochim. Cosmochim. Acta, 32:1037-1049.

Swart, P.K., Burns, S.J., and Leder, J.J., 1991. Fractionation of the stable isotopes of $\mathrm{O}$ and $\mathrm{C}$ in $\mathrm{CO}_{2}$ during the reaction of calcite with phosphoric acid as a function of temperature and technique. Chem. Geol., 86:89-96.

Swart, P.K., and Guzikowski, M., 1988. Interstitial-water chemistry and diagenesis of periplatform sediments from the Bahamas, ODP Leg 101. In Austin, J.A., Jr., Schlager, W., Palmer, A.A., et al., Proc. ODP, Sci. Results, 101: College Station, TX (Ocean Drilling Program), 363-380.

\footnotetext{
- Abbreviations for names of organizations and publication titles in ODP reference lists follow the style given in Chemical Abstracts Service Source Index (published by American Chemical Society).
}

\author{
Date of initial receipt: 2 April 1992 \\ Date of acceptance: 13 October 1992 \\ Ms 133SR-259
}



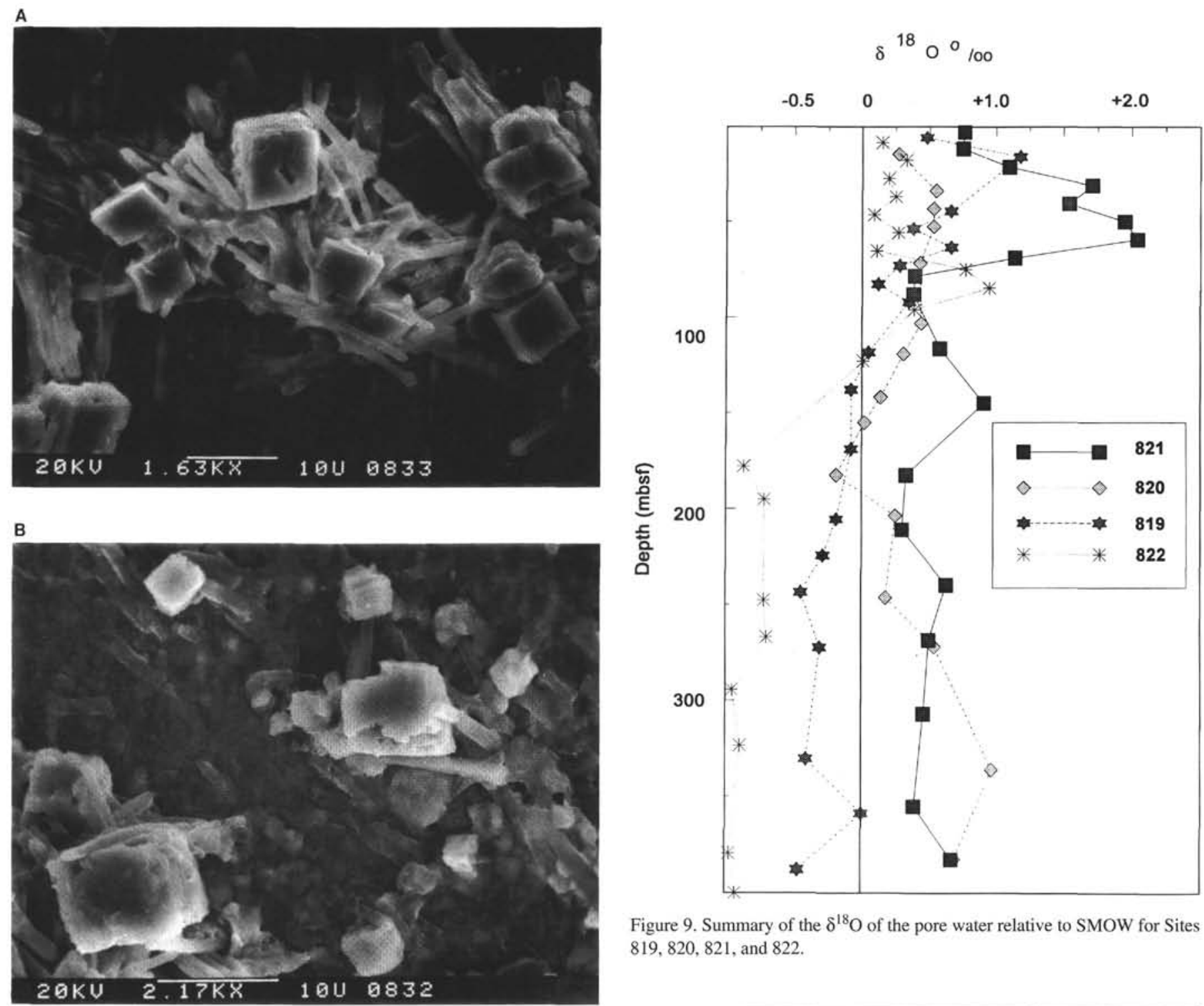

Figure 9. Summary of the $\delta^{18} \mathrm{O}$ of the pore water relative to SMOW for Sites $819,820,821$, and 822 .

Figure 8. SEM photomicrographs of the dolomites isolated from (A) Sample 133-821 A-5H-5, 140-150 cm and (B) Sample 133-821A-13H-5, 140-150 cm.

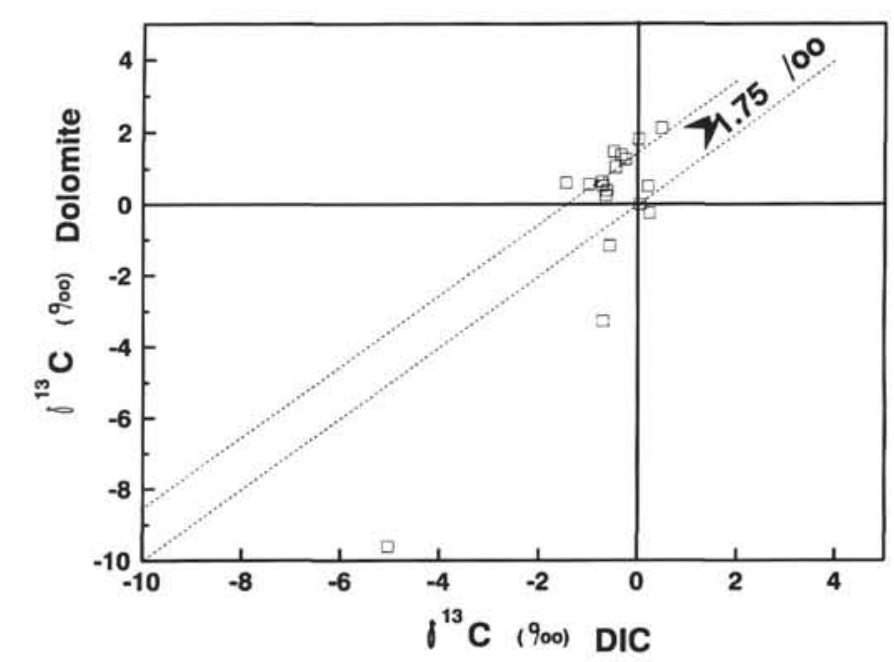

Figure 10. The relationship between the $\delta^{13} \mathrm{C}$ of the DIC and the $\delta^{13} \mathrm{C}$ of the dolomite. 


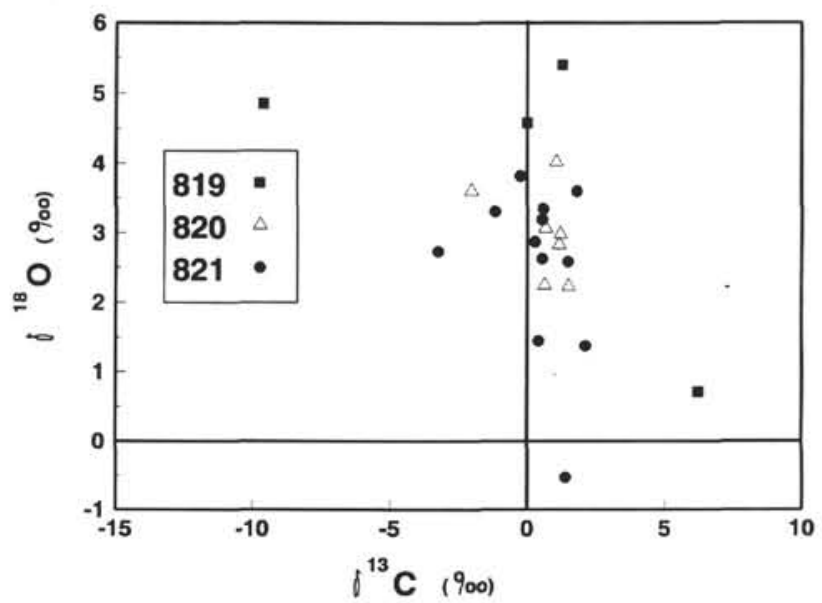

Figure 11. Crossplot of the carbon and oxygen isotopic compositions of the dolomite from Sites 819 to 821 .

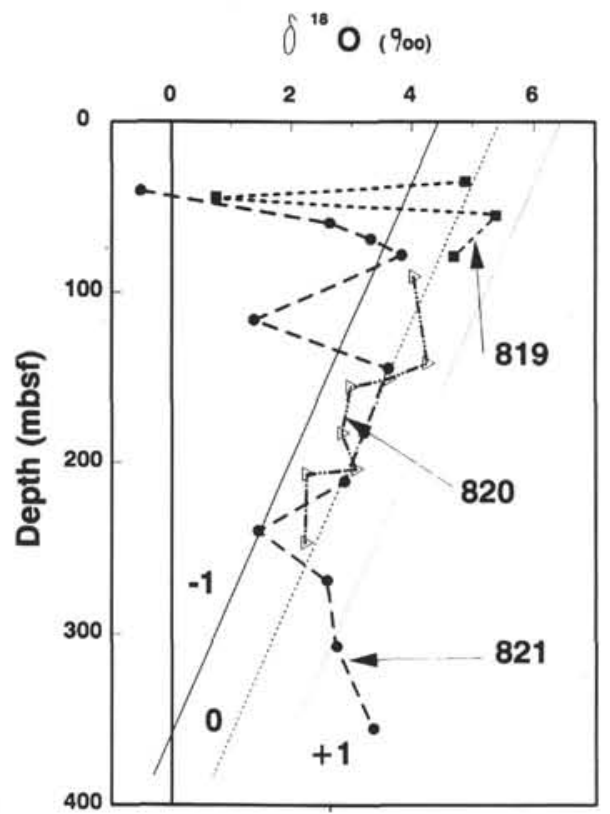

Figure 12. The $\delta^{18} \mathrm{O}$ of the dolomite as a function of depth at Sites 819 to 821 . Also plotted in this figure are compositions of dolomites expected if the dolomite is formed in equilibrium with pore fluids of differing isotopic compositions $(-1,0$, and $+1 \%$ SMOW) with the measured geothermal gradient at these sites. The equation used to calculate the equilibrium values for dolomite is that proposed by Land (1985), which has been modified to take into consideration that these data have been corrected for differences in the fractionation between calcite and dolomite during dissolution by phosphoric acid. 